\title{
Estimation of Radon gas concentration in soil and drinking water supply samples of Kirkuk governorate, Iraq
}

\author{
Muaiad Tahir Ahmed ${ }^{1}$, Mohamed A, Najemalden ${ }^{2}$, Ali A, Abdulwhab ${ }^{3}$ Rehab T.Ahmed $^{4}$ \\ 1 Diyala university \\ 2,3,4 Ministry of environment
}

\begin{abstract}
Radon gas is the second cause of lung cancer and it is found naturally in rocks, soil ground and surface water. In this study, Radon gas concentration measurements were performed in (39) drinking water and (29) soil samples for Kirkuk City. It is found that the value of Radon $(\mathrm{Rn})$ concentration in drinking water ran ged from ( $0.07-5.01$ ) $\mathrm{Bq} / \mathrm{L}$ with an average of ( $0.97 \quad) \mathrm{Bq} / \mathrm{L}$. These results showed that Radon concentration in Kirkuk City drinking water are within the United State Environmental Protection Agency(EPA) and World Health Organization(WHO) standards maximum contaminated level (MCL) of $11 \mathrm{~Bq} / \mathrm{L}$. The finding:- of this study refer that no risk from exposure to Radon gas in Kirkuk drinking water supply. From other hand, Radon in soil results showed that mean values was $(381.65 \pm 189) \mathrm{Bq} / \mathrm{m}^{3}$, with maximum and minimum value 883 and $87 \mathrm{~Bq} / \mathrm{m}^{3}$ respectively. This results lied within the allowable standards adopted by International Commissions of Radon Protection(ICRP) which is (200-800) $\mathrm{Bq} / \mathrm{m}^{3}$. By comparing the results of present study with other local studies in different sites all over Iraq, it can be noticed that the finding of this study were greater than most of other studies results. That difference can be explained due to geological structure diversity of different governorate in Iraq, as Radon gas generated from soil and correlate strongly to soil structure and rock types.
\end{abstract}

\section{Introduction}

Hu man beings are exposed to two source of radiation in their life: natural and manmade radiation, natural sources: include radioactive radon, radioisotopes with along half - life, such as potassium in the body, cosmic rays and some rocks, natural sources of radiation account for $82 \%$ of total exposure for humans beings [1]. Radium is a common radioactive element, one of whose decay, Radon gas, poses health concerns as Radon is the second cause of lung cancer after smoking[2]. Radon generates from rock, soil and underground water as gas. Radon e manating from soil fills the atmosphere but eventually transmutes to other ele ments and is removed . Radon gas has a half-life as short as 3.82 day. it is difficult to detect Radon because it's a colorless and odorless gas. Its atomic number is (86), boiling point $(-61.8) \mathrm{c}^{0}$ and density of( $9.73 \frac{\mathrm{kg}}{\mathrm{m}^{2}}$ ), so it is heavier than air about 8 times, because of that Radon will stay in air of closed areas and make health hazardous [3]. Radon gas can diffuse or be transported to some distance through fissures in the rock structure and find its way into the soil and surrounding materials. Therefore, Radon measurement is the most promising method for detecting uranium deposits [4].

It was not until the early 1970s that radon potential hazard from the inhalation of Radon gas and the daughter progeny in the domestic as urban environment was first identified. In the past, contamination of air by Radon was believed to be a problem only for uranium and phosphate miners. However, it has recently been recognized that homes and buildings far away from uranium or phosphate mines can also exhibit high concentration of radon [5]. Radon exposure has been linked to lung carcinogenesis in both human and animal studies. It has also been associated with the development of acute myeloid and acute ly mphoblastic leukemia and other cancers [6]. Periodical monitoring of radon concentrations had been 
emphasized by many international studies. They proved that the inhalation of short lived decay product of Radon accounts for about one half( $1 / 2)$ of the effective dose equivalent from all natural source of radiation and sometimes lead to cause cancer for human especially lung cancer [7]. The recent key European studies estimated that the risk of lung cancer in human being increased by $16 \%$ per $100 \mathrm{~Bq} / \mathrm{m}^{3}$ increase in Radon concentration. The dose-response relation seems to be linear without evidence of a threshold, that mean the lung cancer risk increase proportionally, with increasing radon exposure, from other hand, the new results find if a threshold exists it should not be higher than $150 \mathrm{~Bq} / \mathrm{m}^{3}$ [8].

Recent studies showed that background level of radon in outdoor air of most American homes are quite low, ranging from $(0.1-15) \mathrm{Bq} / \mathrm{m}^{3}$. EPA (Environ mental Protection Agency of United States) recommends home to be fixed if the radon level is $150 \mathrm{~Bq} / \mathrm{m}^{3}$ [9]. Usually Radon can be found in surface and ground water and then it leaches to drinking water, also, Radon can be exists in drinking water coming from natural spring as a source. Radon evaporates from water used in cooking and bathing and spread to air inside homes and buildings[10] . Radon concentration in water is typically of the order of $100 \mathrm{~Bq} / \mathrm{L}$. United State of A merica drinking water sources surveys, which were done in 2005 showed that $74 \%$ of samples had Radon concentration under $100 \mathrm{~Bq} / \mathrm{L}$, while $5 \%$ had values above $400 \mathrm{~Bq} / \mathrm{L}$ [11] . The major source of Radon in drin king water supplies is well water or groundwater, surface water can be substituted for the groundwater if the Radon concentration was above the united states environmental protection agency Maximum Contaminated Level (MCL) of $11 \mathrm{~Bq} / \mathrm{L}[12]$.

Materials and Methods:

Study area :- This study was conducted in Kirkuk city, north of Iraq. 28 samples of soil, and drin king water, were examined for Radon concentration in different locations inside Kirkuk City. The location were selected to cover different kind of buildings such as :old and new homes, universities, offices and hospitals, to ensure good representing for Radon concentration in the study area. Figure (1) illustrated the sampling locations in the study area. Alpha-guard, professional Radon monitor, (PQ2000 pro) SAPHYMO Gmbh, model 2009, Germany, was used to measured Radon concentration which illustrated in figure (2), the device belong to the Ministry of Environment; Kirkuk Environment Directorate. The study was conducted from April /2013 till August /2015 to applied the Ministry of Environment working plan for Radon gas monitoring. Measuring time was one (1) hour per each sample, soil samples were taken with $20 \mathrm{~cm}$ depth according to Ministry of Environment/ Radiation Protection Center protocol for Radon monitoring.

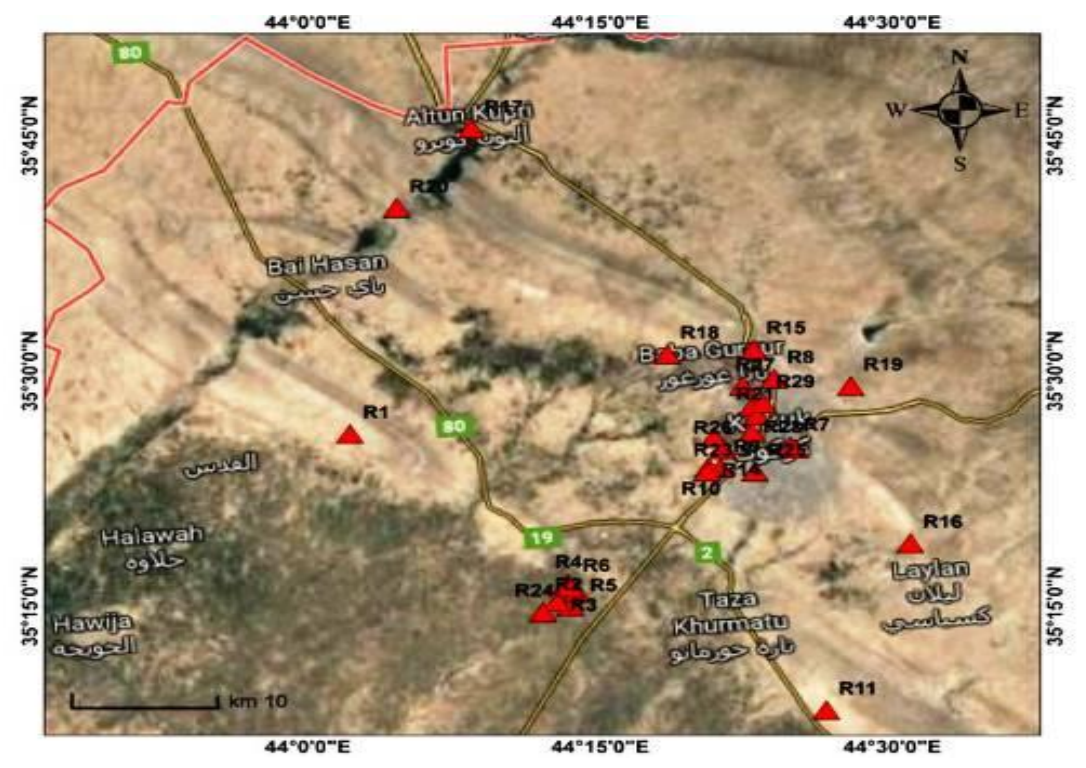

Figure(1) illustrated the sampling location 


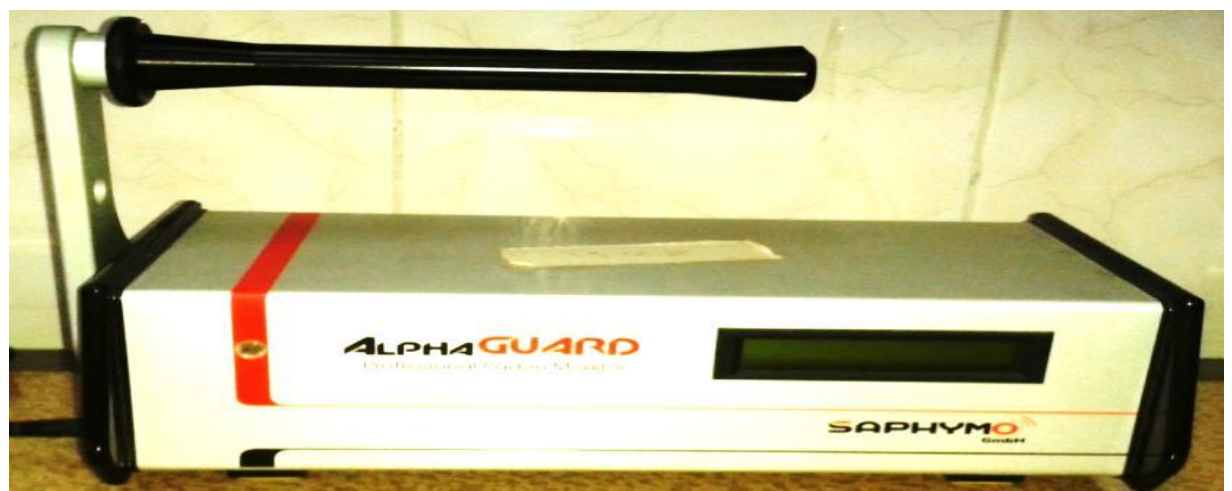

Figure (2) Alpha guard professional radon monitor

Results and Discussion:

Radon concentration in soil, and drinking water are listed in table(1).

Radon in soil : The results showed that mean values was ( $381.65 \pm 189) \mathrm{Bq} / \mathrm{m}^{3}$, with maximum and minimum value 883 and $87 \mathrm{~Bq} / \mathrm{m}^{3}$ respectively as illustrated in Fig (3). This results lied within the allo wable standards adopted by International Commissions of Radon Protection(ICRP) which is (200-800) $\mathrm{Bq} / \mathrm{m}^{3}$ [13]. By comparing the results of this study with other local studies in different sites all over Iraq, which illustrated in table (2), it can be noticed that the finding of this study were greater than most of other studies results. That difference can be explained due to geological structure diversity of different governorate in Iraq, as Radon gas generated from soil and correlate strongly to soil structure and rock types [14].

Radon in drinking water: Radon concentration in drinking water mean value was $(0.97 \pm 1.24)$ with maximum and minimum value 5.02and $0.07 \mathrm{~Bq} / \mathrm{L}$ respectively. All results were lied with in United State Environmental Protection Agency(US-EPA) standards of $11 \mathrm{~Bq} / \mathrm{L}$ [12] .Figure (4), illustrated the above results. Comparing Radon concentration of the present study with other locals studies in different parts of Iraq were shown in table (3), the results of present study were close to most of the previous locals studies:. On the other hand, comparing concentration for recent study with international studies in different countries which shown in table (4).The correlation between soil and drinking water Radon concentration showed positive and weak correlation $\left(\mathrm{R}^{2}=0.0054\right)$, indicates that Radon concentration in drinking water is not depend on soil type as most of drinking water in Kirkuk depend on surface water, see figure (5).

Conclusions: The results of the present study showed that Radon concentration ,both in soil and drinking water, were within international standards, indicating not need for further measurements.

Table(1) sampling location and Radon concentration in soil and drinking water WATERwater

\begin{tabular}{|l|l|l|l|}
\hline ID & & - soil Bq/m3 & drinking water Bq/l \\
\hline R1 & Kirkuk environmental directorate & 320 & \\
\hline R2 & Aden quarter-house & 524 & 0.09252 \\
\hline R3 & Kirkuk municipality garden & 143 & 0.13364 \\
\hline
\end{tabular}




\begin{tabular}{|c|c|c|c|}
\hline $\mathbf{R 4}$ & Al-Tayran square -house & 615 & 0.13364 \\
\hline $\mathbf{R 5}$ & Al-Mansur quarter-house & 546 & 0.32896 \\
\hline R6 & Khasa quarter-house & 336 & 0.07196 \\
\hline R7 & Raperen 2-house & 87 & 0.16448 \\
\hline $\mathbf{R 8}$ & Rahemawa quarter -house & 153 & 0.11308 \\
\hline R9 & Kirkuk technical institute & 227 & 0.13364 \\
\hline R10 & Debis town- AL -bdeer village & 495 & 2.17936 \\
\hline R11 & Dakuk town -health center & 446 & 1.96348 \\
\hline R12 & Al-Shfiaa medical center & 561 & 1.22332 \\
\hline R13 & Al-khadra quarter-house & 664 & 3.598 \\
\hline R14 & Kirkuk technical college & 441 & 0.09252 \\
\hline R15 & Shoraw hospital & 476 & 0.08224 \\
\hline R16 & Laylan town-medical center & 363 & 0.16448 \\
\hline R17 & Altun Kopree -medical center & 299 & 0.17476 \\
\hline R18 & North oil company -hospitals & 353 & 1.2336 \\
\hline R19 & Al-Qalam college & 128 & 2.73448 \\
\hline $\mathbf{R 2 0}$ & Dibs town-medical center & 883 & 1.00744 \\
\hline $\mathbf{R 2 1}$ & Kirkuk children hospitals & 306 & 0.1542 \\
\hline $\mathbf{R 2 2}$ & college of Nursing & 526 & 1.65508 \\
\hline $\mathbf{R 2 3}$ & college of science & 149 & 2.83728 \\
\hline $\mathbf{R} 24$ & Showan town -house & 229 & 1.22332 \\
\hline $\mathbf{R} 25$ & Kirkuk physical therapy center & 203 & 0.08224 \\
\hline
\end{tabular}




\begin{tabular}{|l|l|l|l|}
\hline R26 & Arafa medical center & 353 & 0.57568 \\
\hline $\mathbf{R 2 7}$ & Raperen 1-house & 501 & 0.14392 \\
\hline $\mathbf{R 2 8}$ & Kirkuk general hospital & 597 & 0.26728 \\
\hline R29 & Qernata quarter & 144 & 0.45 \\
\hline
\end{tabular}
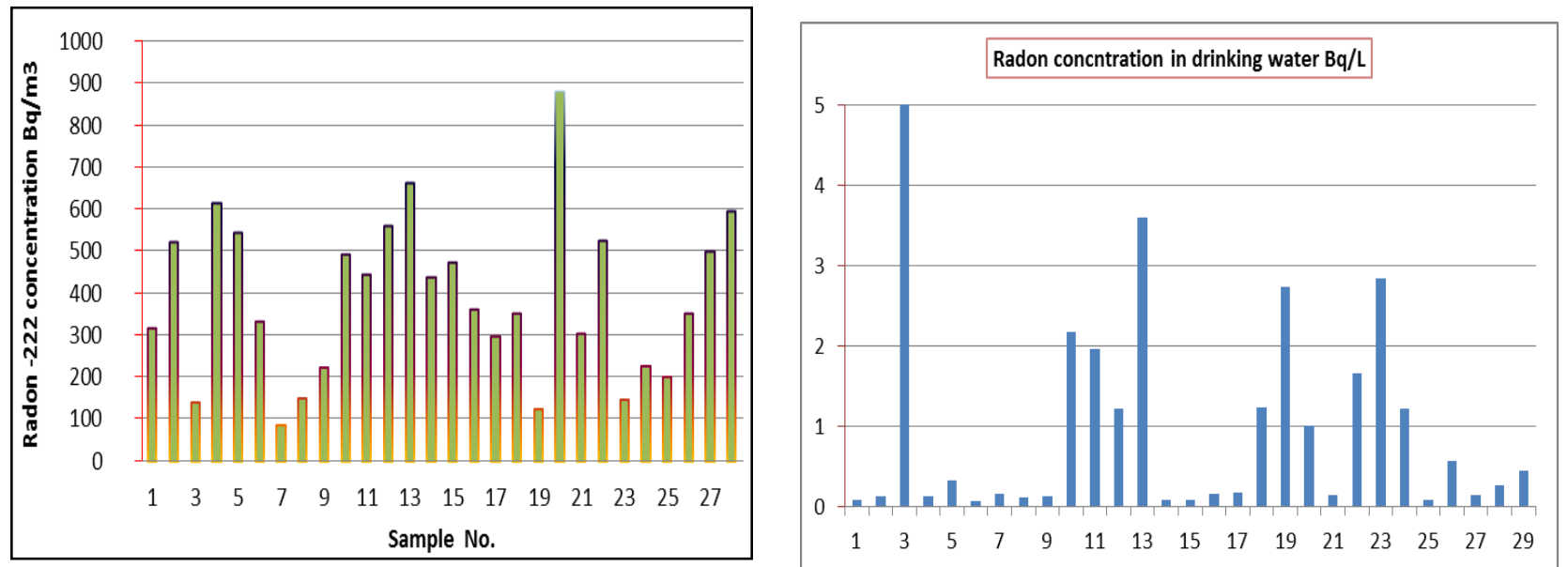

\begin{tabular}{|c|c|c|}
\hline Location/city & Radon in soil $\mathrm{Bq} / \mathrm{m}^{3}$ & Reference \\
\hline Duhok/Kurdistan region & 342.3 & {$[15]$} \\
\hline Al-Anbar governorate / Hit town & 266.4 & [16] \\
\hline Salahdin governorate & 21.9 & [17] \\
\hline $\begin{array}{l}\begin{array}{l}\text { Salahdin } \\
\text { sample }\end{array} \\
\end{array}$ & 11.3 & [18] \\
\hline Al-Anbar/ Falluja town & 95.78 & \multirow{4}{*}{ [19] } \\
\hline Diyala governorate & 23.5 & \\
\hline Baghdad & 43.5 & \\
\hline Wasit governorate & 48.6 & \\
\hline $\begin{array}{llll}\begin{array}{l}\text { Samawa } \\
\text { sample }\end{array} & \text { governorate } & \text { /cement } & \text { dust } \\
\end{array}$ & 10.6 & [20] \\
\hline Kirkuk & 390 & present study \\
\hline
\end{tabular}

\begin{tabular}{|l|l|l|}
\hline Location/city & $\begin{array}{l}\text { Radon concentration } \\
\text { in water } \mathbf{B q} / \mathbf{L}\end{array}$ & Reference \\
\hline Basra governorate & $1.25-21.07$ & 21 \\
\hline Dhi-Qar governorate & $1.63-6.96$ & 22 \\
\hline Nenava governorate & $0.83-1.75$ & 23 \\
\hline
\end{tabular}




\begin{tabular}{|l|l|l|}
\hline Kirkuk city -residential areas & $1.72-5.27$ & 24 \\
\hline Anbar governorate & $2.16-11.88$ & 25 \\
\hline All over Iraq-bottled water & $0.31-7.43$ & 26 \\
\hline Al-Kifel town & & \\
\hline Al-Kufa town & $0.03-1.15$ & 27 \\
\hline Al-Kufa town & $0.26-5.66$ & 28 \\
\hline Erbel city,Kurdistan reigon & $0.04-2.32$ & 29 \\
\hline Baghdad city & $2.01-4.69$ & 30 \\
\hline Hilla city & $0.03-0.15$ & 31 \\
\hline Kirkuk governorate/ different buildings & $0.03-0.11$ & 32 \\
\hline
\end{tabular}

\begin{tabular}{|l|l|l|}
\hline Country & $\begin{array}{l}\text { Drinking water radon } \\
\text { concentration } \mathbf{B} \mathbf{q} \mathbf{L}\end{array}$ & Reference \\
\hline Palestine/ Nablus & $0.9-1.3$ & {$[12]$} \\
\hline Saudi Arabia & $0.76-9.15$ & {$[33]$} \\
\hline India & $1.69-3.97$ & {$[34]$} \\
\hline Syria & $2.8-9.0$ & {$[35]$} \\
\hline India & $0.87-32.10$ & {$[36]$} \\
\hline Turkey & $2.7-34.11$ & {$[37]$} \\
\hline Romania & $0.5-12.9$ & {$[38]$} \\
\hline Iarq-Kirkuk & $0.07-5.02$ & Present tudy \\
\hline
\end{tabular}

\section{References}

[1] Inácioac M., Soaresabc S ,Almeidad P., Radon concentration assessment in water sources of public drinking of Covilhã's county, Portugal, Journal of Radiation Research and Applied Sciences, Volu me 10, No. 2, PP: 135-139, 2017.

[2] Handbook of environ mental engineering,volume 2:advanced air and noise pollution control, edited byL.K.Wang,N.C.Pereira,and Y.T. Hung.The human press,Inc.Totowa. NJ.

[3] K.D .Cliff., 1982.Postgraduate radiological protection course,lec: L137,Harwel,Great Britain.

[4] K.M.Abumurad.,(2001). Chance of lung cancer due to Radon exposure in Al-Mazar AlShamali,Jordan,Radiation Measurment.34,pp:537-540.

[5] Canada mortgage, Housing Corporation and Health Canada,CMHCHC.,(1997).Radon: a guide for Canadian home owners.

[6] United State Nuclear Regulatory Commission Protecting People and the Environment, Biological effects of radiation ,fact sheet,(2011).

[7] Kulwat Singh, Surinder Singh, Rohit Mehra, Manmohan Singh and Z.Papp.,(2006).Measurement of Radon and Thoron progeny outdoor in Malout,India,using grab aerosol sampling and beta counting, Radiation Measurments,vol.41,1,pp:108-111.

[8] D.Krewski, J.H.Lubin, J.M.Zeilinski, M.A lranje, V.S.Catalan and R.W.Field, a Residential Radon and risk of lung cancer: a combined analysis of $7^{\text {th }}$ north America case-control studies,EpideiologyMarch,2005.

[9] Ernesto Vocaturo ,Eva Kunstler, Gariela Slovakova, Juri Runt, Olga Cavoura, Peter Otorepec. Radon levels in dwellings, home,environment and health issues,uv and ionizing radiation,January,2008.

[10] Agency for Toxic Substances and Disease Registry (ATSDR). 2012. Toxicological Profile for Radon. Atlanta, GA: U.S. Department of Public Health and Human Services, Public Health Service. http:// www.atsdr.cdc.gov/toxfags/index.asp.

[11] Ali Gokmem, Inci Gokmen, and Yung-Tse Hung. Radon Pollution Control, In Handbook of Environmental Engineering,volume2: Advanced Air and Noise Pollution Control. Edited by L.K.Wang, N.C.Pereira,and Y.T.Hung.The Human Press,Inc,Totowa,NJ,USA,2005. 
[12] Shaza Issa, S.Musmar and H.Zabadi. Radon concentration measurements in the drinking water supply of Nablus city, Palestine, International graduate conference on science,humanties and engineering,2011, Al-Najah Unversity,Palestine.

[13] Amir Husan Ali Al-Jubory,(2003),Determination of depleted Uranium in the scraps of military equipment in specific locations of south Iraq using HPGE.m.sc thesis, college of science, Mousel university, Iraq.

[14] Huda Sadee Ali.(2012).Measurements of radiation pollution in the dust storm of the city of Tikrit by using the nuclear $\mathrm{CN}-85$,Anbar journal for pure science.6(3).

[15] Radiation control Center, Radon measurements report, printed technical report,Iraq, 2012.

[16]A li Mustfa Mohammad.(2011).Measurements of Radon concentration in soil samples of some sulfuric spring in Hit city using CR-39 detector, Baghdad science jurnal.8(4).pp:972-975.

[17] Ahmed Mohamed Obaid.(2012).Sensitivity and sensing of soil gas Radon pollution in certain area of the province of Salahidin using CR-39 detector, Anbar journal for pure science.5(2).

[18] Huda Sadee Ali.(2012).Measurements of radiation pollution in the dust storm of the city of Tikrit by using the nuclear CN-85,Anbar journal for pure science.6(3).

[19]Nidhala H.Khadim, Dawser H.Ghayb and NoorY.Ahmed, 2011.Radon concentration in soil of Fallujaha, Ramadi, Diayla, Wasit and nearby Baghdad sites using SSNTDS, Iraqi journal of science.52(1),pp:44-47.

[20]Hassan M.Jaber,2013.Measurment of Radon gas concentration in cement samples by using nuclear track detector-LR-115,Kirkuk university journal-scientific studies.8(3),pp:48-54.

[21]Al-KhaliFa, I.J.M.,Najim H. and Baker H. Determination of Radon concentration in ground water of Basrah governorate by using solid state nuclear track detectors. Journal of Kufa-physics.special issue Kufa first conference for physics.PP:114-124,2010.

[22] H.A.Hammood and I.J.M.Al-Khalifa.Radon concentration in water of Dhi-Qar governorate using Emanometer.Journal of Basrah researches.volume.37.No.5.2011.

[23] Saeed. H and Sabah Y. H Determination of Radon ,Uranium and other radioactive isotopes concentration in different type of natural water in Neneva. governorate,Jordinan journal of physics,volume8.No.4.pp227-244.2015.

[24] Najeb F.S., Zubir M.,J and Mohamad S.,J. Measurement of Radon and Uranium concentration in drinking water in Kirkuk governorate. Journal of scientific research and development. Volu me2,No.13, pp127-133,2015.

[25] Dhameer A.Mutlak. Talal A.A lani. and Ahmed Farhan. Determination of Radon gas concentration and annual effective dose in groundwater samples in some region in Anbar governorate. Journal of college of education. Volume1,No.1,2015

[26] Abdalsattar K. Hashim and Rajaa Hussien Abd Ali, Measurement of Annual Effective Doses of Radon in Plastic Bottled Mineral Water Samples in Iraq. Australian Journal of Basic and Applied Sciences, Volume9,No.5, 2015, PP: 31-35.

[27] Khalid H. Hatif, Mohsin K, Muttaleb and Alyaa H. Abass, Measurement of Radioactive Radon Gas Concentrations of Water in the schools for Kifel, world scientific news journal Volume54,PP: 191-201, 2016.

[28] A.A.Al-Hamadwi ,A.A.Al.Bayati and A.H.Al.Mashhadani, Radon and Thoron Concentration measurement of Ground Water in Kufa City by using RAD7 detector, Journal of Kufa - physics, Volume.4 No.2,2012.

[29] Ali A. Abojassim, Radon Concentrations Measurement for Drinking Water in Kufa

City /Iraq Using Active Detecting Method, Advances in Physics Theories and Applications,Volume26,PP:30-35,2013.

[30] Asaad H. Ismail and Salih O. Haji, Analysis of Radon Concentrations in Drinking Water in Erbil Governorate (Iraqi Kurdistan) and its Health Effects, Tikrit Journal of Pure Science Volume. 13 No. 3, 2008.

[31] Seja F. Hassan, Measurement of the radon gas emanation fro $m$ drin king water samples from regions in northwest Baghdad governorate by using nuclear track detector (CR-39), Journal of college of education,No3,2016. 
[32] Mohsin K. M. Al-jnaby, Radon Concentration in Drinking Water Samples at Hilla city, Iraq, world scientific news journal, Volume. 52 ,PP: 130-142,2016.

[33] Wadad R.Alharbi, Adel G.E.Abbady ,and El-Taher A, Radon concentration measurements for groundwater using active detecting method, American Scientific Journal for Engineering, Technology, and Science,volume14.No 1.PP 1-11,2015.

[34] R. G. Sonkawade, Rewa Ram, D. K. Kanjilal and R. C. Ramola, Radon in Tube-Well Drinking Water and Indoor Air, Indoor and Built Environment,volume13,PP383, 2004.

[35] Showekani R and Rejaa G, radiation activities in drinking water Hems city, Sy ria, technical report No.789, Syrian atomic commission, republic of Syria, 2008.

[36] JogaSingh, Harmanjit Singh ,Surinder Singh, B.S.Bajwa, Estimation of uranium and radon concentration in some drinking water samples, Radiation Measurements, Elsevier Radiation Measurements, Volume 43, No. 1, PP523-526, 2008.

[37] OktayBaykara and Mahmut Dog ru, Measurements of radon and uranium concentration in water and soil samples from East Anatolian Active Fault Systems (Turkey), Radiation Measurements, Volume 41, No. 3, PP 362-367, 2006.

[38] Cosmaa C, M.Moldovan, DicuaT, Kovacsb T., Radon in water from Transylvania (Romania), Radiation Measurements, Volume 43, No. 8, PP 1423-1428 , 2008. 